\title{
SUPPORTING THE SRI LANKAN NATIVE BIRD SPECIES JUNGLE FOWL IN ANALOG FORESTRY
}

A.N Lokuge \& K.L.G.H. Sanjeewa

Neo Synthasis Reseasrch Station

An experiment donc at model Analog.Forestry of Belipola Estate, Mirahawatte, Sri Lanka indicates that an array of native and exotic crops determined by studies and trials made jungle fowl to re-establish, carry out main life activitiès and thrive in this anthropogenic ecosystem of proper design. 